\title{
Social Fear of Crime and Its Consequences
}

\author{
Leszek Wilk ${ }^{1}$, Bogdan Fibinger ${ }^{1}$ \\ ${ }^{1}$ Department of Law and Social Sciences, Bielsko-Biała School of Finance nad Law \\ Tańskiego 5, 43-300 Bielsko-Biała - Poland
}

\begin{abstract}
Social fear of crime is a phenomenon of interest to scientific disciplines. The present study draws primarily on the achievements of criminology. It shows that there are different ways of interpreting fear of crime, explaining its causes and responding to it. The conclusions also depend on the perspectives - whether it is the perspective of an individual, small social groups or large social structures. There are always objective and subjective elements in evaluations, including irrational ones. The latter hinder rational criminal policy. Fear of crime has negative social consequences, such as a loss of citizens' sense of security, aggressive attitudes, a loss of trust in law enforcement services, a reduction in the need for social contact, a reduction in the willingness to provide assistance - as a result, an increase in crime and an even greater sense of threat, particularly affecting socially weaker groups. The rigour and emotional approach to the problem of punishing criminals, resulting from the fear of crime, gives rise to the phenomenon of so-called penal populism, often used by politicians with the participation of the media. Finally, the economic costs of social fear of crime are not insignificant.

For these reasons, the phenomenon should not be underestimated, but should not be overestimated, because in the context of other threatening situations and various dangers, it does not constitute the main feeling of threat to citizens and is far behind such fears as social, economic, health, fear of war, etc. Favourable developments in areas other than internal security, e.g. increased prosperity reduces social fear of crime more than restrictive criminal law.
\end{abstract}

Index Terms - fear, society, crime, social rigorism, penal populism

\section{INTRODUCTION}

This study attempts to answer the questions - what factors determine the level of social fear of crime, how serious the phenomenon is in terms of its social impact and what is the most appropriate response to it. The phenomenon indicated in the title of this paper has an interdisciplinary scientific background. It can therefore be described and explained from the perspective of different sciences. This paper is essentially based on scientific publications included in the bibliography of the science of criminology, using a methodology specific to that science, i.e. describing the phenomenon under investigation and

ASEJ - Scientific Journal of Bielsko-Biala School of Finance and Law

Volume 24, No 1 (2020),5 pages

DOI: $10.5604 / 01.3001 .0014 .1353$

Received: 06 April 2020; Accepted: 10 April 2020 explaining its causes and effects, which should not come as a surprise if one considers that the title phenomenon refers to crime which is the focus of the science of criminology. It should be remembered, however, that criminology is an interdisciplinary science, based on the achievements of other sciences, not only social ones, such as sociology, psychology, medicine, including psychiatry and others. The growing feeling of being threatened by crime in many modern societies has not been a subject of much interest from science and practice for a long time. It was only as a result of surveys of crime victims and the state of crime that this phenomenon was also considered to be socially significant (Hołyst, Kube 1995).

From the psychological point of view, a certain confusion or inconsistency in terminology can be observed. Such terms as fear, fear or anxiety are used to describe the discussed phenomenon, sometimes interchangeably (Hołyst, Kube 1995). In some authors there is a distinction between the notions of anxiety and fear, which is to consist in the fact that anxiety is an emotional reaction not connected with a specific cause or situation, while fear is an emotional reaction to an objective, recognizable external threat. These terms are often used interchangeably, based on the similarity between them, consisting in the fact that they define certain emotional reactions accompanied by similar somatic reactions (Błachut, Gaberle, Krajewski, 2004). Other authors distinguish between fear and anxiety. They see fear as defining the human being's mood. It is supposed to be a constant, often uncomfortable and sometimes paralyzing factor in our lives. It is said to be an expression of a far indefinite sense of threat and "images of sensitivity" of a human being. It occurs as a result of a more or less conscious assessment of the threat, namely when one's own ability to control the situation is judged to be insufficient. Fear means not only a negatively perceived threat, but sometimes also an "appeal and warning", can even contribute to the development of personality (Hołyst, Kube 1995).

The term "fear" is often used as a synonym for "fear". Even in the psychological literature there is no clear distinction between the two concepts. When it comes to criminologists, some prefer the term "fear of crime", others prefer the term "fear of crime". Those who differentiate between the two concepts claim that fear is not directed towards something specific, but

Regular research paper: Published 30 April 2020

Corresponding author's e-mail:lwilk@wsfip.edu.pl;

bogfib@gmail.com

Copyright (C) 2018 This is an open access article distributed under the Creative Commons Attribution CC-BY-NC 4.0 License. 
focuses on the subject's attitude towards himself, while fear is related to an object. Whoever is afraid knows what. If one feels threatened by many things, by something unspecified, then in the absence of a clear reference to the subject, fear turns into fear. While fear usually paralyses, and in some cases causes aggressiveness, this fear can in principle - in unclear situations - serve as a kind of compass (a measure of behaviour).

Criminologists who make such views are of the opinion that the primary objective of criminal policy should be to prevent the fear of crime from turning into a fear of crime (Hołyst\&Kube 1995). From the point of view of criminology, which is an ancillary science to the science of criminal law, it seems that the differences and discrepancies in terminology should not be overestimated. Whether we use the term "fear" or "fear" or, finally, "fear" in relation to crime, it is important from a social as well as a legal point of view that we are talking about a certain psychological and social construction which, like the social attitude, consists of certain components and has certain consequences. These are important, not terminology.

In a criminal case, e.g. for a crime committed against a foreigner - an immigrant - the question arises whether it resulted from an unspecified "fear" of "strangers" and resulting hatred for them, or from a "fear" of immigrants due to a specific danger of losing one's own property (e.g. employment). It is important to answer this question, not the terminological subtleties against the background of the distinction between "fear" and "fear".

For a criminal lawyer using statutory concepts of criminal legislation such as 'motives' or 'wake up'(Filar, 2010s p. 580), the aforementioned terminological differences seem to have little meaning, at least in practice. For the purpose of this study, the term contained in its title - 'fear of crime' - has been adopted, because such a term dominates in contemporary Polish criminological and victimological literature, and, as already mentioned, both of these sciences to a large extent refer to sociology, psychology and other social sciences.

\section{COMPONENTS OF THE FEAR OF CRIME TITLE}

In the criminological literature, three components are nowadays distinguished in the concept of fear of crime (Błachut, Gaberle, Krajewski 2004):

1) The first one is the component called affective (emotional), whose indicator is a subjective feeling of security or danger, experienced in everyday life, and the fear of victimisation, i.e. the possibility of becoming a victim of crime. In empirical research, feelings of security are usually measured by asking questions such as "are you afraid to walk alone at night in the area where you live", "do you feel safe in your flat at night when you are alone", "is there any place in your area where you are afraid to walk alone during the day", etc., etc.In turn the fear of victimisation is measured by questions of the type - "do you feel a fear of becoming a victim of a crime of burglary, theft, robbery, rape, etc.".

2) The second component of the concept of fear of crime is the component called cognitive (rational). Its indicator is to assess the development of crime and the probability (risk) of victimisation. The assessment of the development of crime is examined by asking questions such as "do you think that crime (in general, or certain categories of crime) has been increasing or decreasing in recent times, e.g. over the last three years? The probability of victimisation is examined by asking questions such as "do you think, do you think, do you think, that in the next e.g. 12 months, you may become a victim of one or another crime". The assessment of the risk of victimisation should not be mixed up with the fear of victimisation, because despite the assessment of the probability of becoming a victim of e.g. a robbery as a small one, you may feel fear of this crime, while e.g. a young, strong and experienced in combat sports man, despite the high probability of becoming a victim of a robbery to a small extent, or does not feel fear of a robbery at all.

3) The third component of the notion of fear of crime is the component called conative (behavioural). Its indicator is the precautions taken by the individual to protect himself against crime and avoid victimisation. These precautions are divided into defensive measures, such as the installation of alarm systems and evasive measures, which consist of avoiding certain places or contacts with certain persons judged to be dangerous. The tool for measuring the conceptual indicator is questions about these defences and evasive measures. For example, the questions listed above measure the various components of the fear of crime. Depending on the level of the individual components, there are different ways of interpreting the fear of crime, explaining its causes and responding to it (Błachut, Gaberle, Krajewski 2004).

It follows from the above that investigating and explaining fear of crime is not an easy task, as this phenomenon is determined by various variables. A difficult problem is to select the variables that are important for explaining the phenomenon, to determine the degree of their significance, direction and nature of their impact. The literature points out that some studies (e.g. British) show that the citizens questioned in the questionnaires actually have unclear ideas about their fear of crime, as well as incorrectly formulated questions in the questionnaires may lead to wrong conclusions, hence the need for a very careful assessment, which is not easy(Hołyst 2011, p. 928). Fear of crime is measured either in relation to one crime, type (generic category) of crime, or to several types of crime.

\section{DIMENSIONS OF EXPLAINING THE PHENOMENON OF FEAR OF CRIME INTRODUCTION}

Explaining the fear of crime can be done on three levels or from three perspectives (Błachut, Gaberle, Krajewski, 2004). The first one is the victimisation perspective explaining the phenomenon on an individual (entity) level. It is based on the assumption that fear of crime is the result of individual victimisation experiences. From this perspective, it is assumed that a person with victimisation experience generally reveals a higher level of fear of crime than a person without such experience, and that he or she more often takes precautions 
against crime. The second perspective of explanation is the perspective of social control, explaining the discussed phenomenon at the level of small social groups (the so-called first degree structures). From this perspective, it is assumed that fear of crime is a consequence of the disintegration of the sense of community (ties) and loss of informal social control in the immediate environment. The functioning of informal control may be affected by the actual disintegration of bonds caused by social disorganisation, as well as the perception of certain external symptoms of so-called incivilities as manifestations of social disorganisation. The occurrence of damaged buildings with windows and graffiti on the walls in certain areas of the given village, or the wandering of groups of strangely looking young people, drunks, etc., may cause the inhabitants to believe that this area is dangerous, even though this is not really the case. Finally, the third perspective of explaining the fear of crime is the perspective of a social problem, explaining this phenomenon on the level of large social structures (the socalled second degree structures). Here attention is drawn to the role of the mass media in creating social problems. It should be stressed, however, that the media image of crime can be treated by certain interest groups instrumentally, in order to confuse society about the real social threats. In particular, the persistent fear of crime is often the result of the media dramatising violent crime in the first place. On the other hand, the media rarely provide accurate information on the state of crime, except in cases of serious and appalling crime (Hołsyt, Kube, 1995 p. 27).

In the light of the above, there is no doubt that objective and subjective elements, including, to some extent, irrational elements, are present in the assessment of the level of fear of crime (Wieczorek 2007). The latter are variable, depending on the culture, but they nevertheless hinder rational criminal policies and efforts to reduce widespread fear of crime. However, there is an opinion in the literature that such actions are necessary (Hołyst\&Kube 1995 p. 37). Quite commonly accepted is the view expressed by one of the authors that it is worth doing something so that all citizens can not only take to the streets in the evening, but also believe that they can do it (Hołyst\&Kube 1995 p. 37). The growing fear of crime not only affects the deterioration of living standards, but can also be a criminogenic factor, and is finally socially destabilising. Just as in the case of the emotional sensitivity of societies to other dangers, such as those arising from nuclear energy (Chernobyl) or war, also in the case of dangers arising from crime "the shell of systemic trust over the volcano of fear is particularly thin" (Hołyst\&Kube 1995 p. 37).

\section{THE CONSEQUENCES OF FEAR OF CRIME}

Fear of crime is a phenomenon that cannot be ignored for at least several reasons. The loss of security causes many people to become violent, which creates the danger of escalating violence (Wojciechowska 1998 p.40). Public confidence in the police and other law enforcement services can be lost, which in turn can significantly affect public willingness to cooperate with the police and other services in fighting and preventing crime. Literature reports show that fearful people are often sceptical of the police in advance and tend to take the view that "they have not grown up to their task" (Hołyst, Kube 1995 pp. 33-35). Security campaigns tend to reinforce this fear, as sceptics in particular are confirmed by the fact that their fear is right when security is under discussion. Another possible, relatively permanent negative effect of persistent fear of crime is also pointed out. It can especially prevent residents of large cities from staying away from home, especially after dusk. As a result, streets and city squares remain and are not very frequented. Those who have to be there by necessity will probably experience an increased sense of danger (Hołyst, Kube 1995 p. 35). The state of insecurity negatively affects the need for contacts, as well as the readiness to help. The perception of this fact by potential criminals may stimulate them to commit crimes, as the criminal activity appears to be less dangerous. In such situations, self-defence of victims becomes problematic, which is difficult to expect. Intervention by third parties also becomes unlikely. Notifying law enforcement authorities is doubtful. As a result, it may determine the increase in crime and this in turn strengthens the subjective assessment of reality in society. In such developments, the danger factor often shifts the risk of becoming a victim of crime to the socially "weaker". - e.g. whoever relies on public means of communication may be exposed to greater risk as a result (Hołyst\&Kube 1995 p. 34).

An important possible and real effect of the loss of feeling of security in societies is the emotional approach to the problem of punishing criminals, which increases the rigour of society, as our country is an example pointed out in the literature (Wojciechowska 1998 p. 40; Szumski 1993 pp. 240-241; Kaczmarek 2007 p. 521; Krajewski\&Kury 1998, p.100). This rigorism manifests itself in the postulates of increasingly severe punishment, and even in the opinions issuing testimonies to their authors that are even embarrassing, e.g. to punish criminals with flogging, cut off thieves' hands, or execute sentences in a public place. The rigour found in public opinion polls is therefore not limited to the preference for imprisonment or declaring support for the death penalty. The results of the research indicate that in most countries of the world, not only in Poland, for a number of years we have been dealing with an increase in the punitiveness of social attitudes (Krajewski, Kury 1998 p.87). The issue of increasing the sense of security and thus reducing social fear of crime very often arises during election campaigns, in which actions disproportionate to the actual threat of crime are often proposed, referring in many countries mainly to young people, foreigners and sex offenders (Hołyst 2011 p.927). Fear of crime therefore generally takes on a negative criminological significance in practice from a criminal policy point of view. This circumstance seems to be one of the most important, if not the main negative social consequence of fear of crime, since a public opinion that expresses a high level of fear and a feeling of being threatened by crime while at the same time declaring a strongly punitive attitude becomes a particularly desirable point of reference for the authorities, which, by aiming at a clear increase in criminal repression along this path, obtains spectacular and sufficient support and legitimacy for their strategy of "introducing law 
and order". Criminal literature points out that in such a case it is difficult to expect lawmaking to be a rational activity, purged of "magic" elements. In addition, the publicised problem of fear of crime contributes to the enormous expenditure of citizens on their own security. Literature points to the listing of huge profits by the private security industry in countries such as Germany (Kaczmarek 2007, p.521).

\section{FEAR OF CRIME IN THE CONTEXT OF OTHER SOCIAL RISKS}

Undoubtedly, the problem of social fear of crime should not be underestimated. In countries where this problem has been completely underestimated for a long period of time (e.g. Sweden), it becomes very clear, becoming one of the most burning problems (Hołyst 2011). On the other hand, however, it is noted that the fear of crime in the lives of citizens does not play such a role that is stereotypically attributed to it. The point is that fear of crime should be seen in the context of other threatening situations and assessments of various dangers, otherwise it gives the misleading impression that it is the main threat to citizens (Hołyst 2011). German research indicates that fear of crime, compared to other social fears, takes the penultimate place after fears of a worsening of the economy, an increase in the cost of living, loss of work, serious illness, terrorist attacks, alcoholism and drug addiction of own children or an influx of foreigners. The respondents therefore consider other dangers than becoming a victim of crime to be much more dangerous (Hołyst 2011). Characteristic - as far as German opinion is concerned - is the increase in recent years in the level of fear of terrorist attacks, unemployment and war in which Germany would participate (Hołyst 2011). According to some authors, positive developments in areas of society other than internal security limit the possible negative impact of increased crime on the sense of security (Hołyst, Kube, 1995). If prosperity grows, the sphere of insurance protection expands, it creates a kind of "buffer", which allows citizens to endure more easily and thus have less fear of e.g. crimes against property, which is the statistically most common category of crime (Hołyst, Kube 1995). The same applies, for example, to women's perception of the threat of crime. Women are more vulnerable than men in their sense of security expressed in research. However, the growing empowerment of women and their increasing integration into public life is leading to a clearer self-awareness. Fewer and fewer women feel powerlessly exposed to crime, especially violent crime. The scope for subjectively perceived harm is therefore diminishing. American research shows that the level of fear of crime is significantly related to satisfaction with the quality of life, satisfaction with the quality of services, satisfaction with the quality of institutions, home and personal security (Hołyst 2011). Therefore, fear of crime should not be considered and assessed in isolation, but as one of the various social fears and anxieties, bearing in mind that interactions between different social problems, including social pathologies, translate into social attitudes, including emotional ones, such as fear relating to particular problems and pathological phenomena.

\section{FEAR OF CRIME IN THE CONTEXT OF OTHER SOCIAL RISKS}

Undoubtedly, the problem of social fear of crime should not be underestimated. In countries where this problem has been completely underestimated for a long period of time (e.g. Sweden), it becomes very clear, becoming one of the most burning problems (Hołyst 2011), (Malec1980). On the other hand, however, it is noted that the fear of crime in the lives of citizens does not play such a role that is stereotypically attributed to it. The point is that fear of crime should be seen in the context of other threatening situations and assessments of various dangers, otherwise it gives the misleading impression that it is the main threat to citizens (Wojciechowska 1998). German research indicates that fear of crime, compared to other social fears, takes the penultimate place after fears of a worsening of the economy, an increase in the cost of living, loss of work, serious illness, terrorist attacks, alcoholism and drug addiction of own children or an influx of foreigners. The respondents therefore consider other dangers than becoming a victim of crime to be much more dangerous (Kaszycki 1991), (Wojciechowska 1998). Characteristic - as far as German opinion is concerned - is the increase in recent years in the level of fear of terrorist attacks, unemployment and war in which Germany would participate (Hołyst 2011). According to some authors, positive developments in areas of society other than internal security limit the possible negative impact of increased crime on the sense of security (Wojciechowska 1998). If prosperity grows, the sphere of insurance protection expands, it creates a kind of "buffer", which allows citizens to endure more easily and thus have less fear of e.g. crimes against property, which is the statistically most common category of crime (Wojciechowska 1998). The same applies, for example, to women's perception of the threat of crime. Women are more vulnerable than men in their sense of security expressed in research. However, the growing empowerment of women and their increasing integration into public life is leading to a clearer self-awareness. Fewer and fewer women feel powerlessly exposed to crime, especially violent crime. The scope for subjectively perceived harm is therefore diminishing. American research shows that the level of fear of crime is significantly related to satisfaction with the quality of life, satisfaction with the quality of services, satisfaction with the quality of institutions, home and personal security (Błachut, Gaberle, Krajewski 2004). Therefore, fear of crime should not be considered and assessed in isolation, but as one of the various social fears and anxieties, bearing in mind that interactions between different social problems, including social pathologies, translate into social attitudes, including emotional ones, such as fear relating to particular problems and pathological phenomena.

\section{CONCLUSION}

The above brief outline of the problem of fear of crime should be summed up by correcting the mistaken impression that, on the basis of the results of the research and the political requirements based on them, it is supposed to be a complete 
removal of fear of crime and a world free from crime, while other, much greater real threats of the modern world would be treated as less important.

It is also worth realizing that freedom and security are two goods that are at least to some extent mutually exclusive, which should by no means be treated as praise of totalitarianism. On the other hand, the growing fear of crime and the lack of appropriate counteraction can be used by certain political circles to gain authoritarian power. This circumstance, as well as other, multiple negative social consequences of the phenomenon in question, speak against underestimating it, but instead of drastically increasing the level of criminal repression, systemic actions seem more appropriate, especially in the social, economic, cultural and educational spheres.

\section{REFERENCES}

J. Błachut, A. Gaberle, K. Krajewski-(2004), Kryminologia, Gdańsk

B. Hołyst, E. Kube(1995) - Strach przed przestępczością - zaniedbany problem polityki kryminalnej, Prokuratura i Prawo, nr 1

M. Filar (ed.)(2016) - Kodeks karny. Komentarz, Warszawa.

B. Hołyst(2011) Wiktymologia, Warszawa

L. Wieczorek(2007) Obiektywna i subiektywna ocena strachu przed przestępczością w opinii studentów wybranych kierunków studiów [in:] A. Czerkawski, A. Nowak (red.) - Wybrane zagadnienia patologii społecznej iresocjalizacji, Katowice

T. Kaczmarek(2007) Racjonalny ustawodawca wobec opinii społecznej a populizm penalny, Archiwum Kryminologii 2007-2008 t. XXIX-XXX

J. Wojciechowska (1998) Wzrost przestępczości jako źródło obaw i niepokojów mieszkańców Warszawy, Czasopismo Prawa Karnego i Nauk Penalnych 1998, nr 1-2

K. Krajewski, H. Kury(1998),Punitywność społecznych postaw wobec przestępczości. Przegląd wyników badań, Czasopismo Prawa Karnego i Nauk Penalnych nr 1-2

R. Kaszycki(1991), Społeczne poczucie zagrożenia przestępczością, Problemy Praworządności,

J. Malec(1980) Poglądy społeczeństwa polskiego na przestępczość (wyniki badań), Warszawa. 